\title{
Deteriorated Water Quality as a Comparative Measure to Analyzethe Development Rate of Cities: A Case Study of Maharashtra, India
}

\author{
Priyanka K. Gadhave and Akanksha Haribhau Kawade
}

\begin{abstract}
The growing water pollution is a major issue of concern for environmentalists all over the world. Water pollution is induced in cities due to the harmful and deleterious effluents from industries and also domestic sewage. The influx of these contaminants alters the physico-chemical and biological nature of the water in which they are disposed making rivers their largest victims. In the present paper, a conscious attempt has been made to study the impact of pollution river water ecology. Water samples from three industrially developing cities were taken at locations where the river enters and leaves each city. The changes in nature of the riverine water were evaluated on the basis of water quality parameters namely PH, BOD, COD, DO, total suspended and dissolved solids, total hardness, chlorides and sulphates. The total coliform count and feacal coliform is also used as an indicator. The results of these tests are represented graphically giving an implied relationship between increased industrial development and deteriorated water quality. The probable measures to curb these pollution hazards have also been discussed.
\end{abstract}

Index Terms-Domestic sewage, development rate, industrialization, pollution, water quality parameters.

\section{INTRODUCTION}

Water is the most essential and undisputed commodity necessary for the survival of mankind and also for its development. Many of the ancient civilizations have flourished along rivers banks and have brought in the trend for economic stability. This urge for economic selfsufficiency laid the seeds of industrial revolution. Industrialization carries along with it the shadows of deterioration and pollution of the environment particularly water. This leads to more water being consumed and more waste being created. The easiest method of disposing this waste was dumping them in water bodies without realising its pernicious impact on their biota. This situation is not only seen in the developed nation but also in the developing nations like India which is progressing rapidly on account of industrialization. Most of the rivers in the urban areas of the developing countries are the ends of effluents discharged from the industries [1]. According to statistical data Pune is at the forefront of development followed by Nasik and Kolhapur. Pune has about 25000 industries with 600 large

Manuscript received April 17, 2014; revised June 12, 2014.

Priyanka K. Gadhave is with the Department of Mechanical Engineering, Maharashtra Institute of Technology, Pune, Maharashtra, India - 411038 (e-mail: priyankag_7@yahoo.com).

Akanksha H. Kawade is with the Department of Environmental Engineering, Kolhapur Institute of Technology, Kolhapur , Maharshtra, India (e-mail: akankshakawade7@gmail.com). scale projects [2]. Nasik has about 8000 industries and Kolhapur about 1100 [2].

The city which has the maximum number of industries with a large workforce indirectly has the largest population using more water and producing more domestic sewage. Off the total waste water generated in Pune including domestic and industrial effluent, about one-fifth is let into the river untreated [2]. The situation in Nasik and Kolhapur is no different. These contaminants are disposed of in river water. At the source of a river, the water is relatively pure as it flows towards downstream [3]. Hence, water entering the city is more pure than the water that leaves the city implying pollution problems to all those who consume it along its course of flow.

In the state of Maharashtra about $52 \%$ of the total water available is contributed by Godavari, Krishna, Tapi and Narmada basins [4]. The major rivers in these basins are namely Godavari, Mula-Mutha and Panchganga. This same water is supplied to the residents for consumption in these cities. These cities are selected for research as their water sources are undergoing rapid pollution. No such comparative study has been taken up for them before. Suggestive measures have also been stated to improve these conditions and to make the rivers sustainable to suffice the needs of the future generations.

\section{MethodS AND MATERIALS}

\section{A. Study Area}

The study areas are 3 cities of Pune, Nasik and Kolhapur located as Pune: 18 ' 32 '” N and 73' 51' E with Mula-Mutha as prime river, Nasik: $20^{\prime} 0 " \mathrm{~N}$ and $766^{\prime} 0$ " $\mathrm{E}$ with river Godavari and Kolhapur: 16' 42" N and 74' 16" E with river Panchganga.

\section{B. Sample Collection and Analysis}

The samples were collected from six stations. Two stations of each city i.e. the entry point and exit point for each river through the city. Station 1(Khadakwaslagaon) as entry and station 2(Lonikalbhor) as exit for Pune.Station3 (Tapovan) as exit and station 4(Gammat-Jammat bridge, Gangapur) as entry for Nashik. Station 5(Panchganga bridge) as exit and station 6(Panhala bridge) as entry for Kolhapur.

All the samples at the entry and exit for each city were collected in one day. 1 litre of sample from each location was collected in sampling bottles as per (standard method, 1998). $300 \mathrm{ml}$ of sample from each location was collected in sterile bottles for microbial tests. Microbial tests were 
carried out within 5 hours and physicochemical tests were carried out within 24 hours of sample collection. All the tests were done as per IS codes. All the names of the tests and there IS codes are mentioned in Table I.

TABLE I: TESTS AND THERE IS CODES [5]

\begin{tabular}{|c|c|}
\hline TABLE I: TESTS AND THERE IS CODES [5] \\
\hline Tests & IS codes \\
\hline PH & IS 3025 P-11: 1983 \\
\hline Dissolved oxygen & IS 3025 P-38: 2009 \\
\hline $\begin{array}{c}\text { Biochemical oxygen } \\
\text { demand(BOD) }\end{array}$ & IS 3025 P-44: 1993 \\
\hline $\begin{array}{c}\text { Chemical oxygen } \\
\text { demand(COD) }\end{array}$ & IS 3025 P-58: 2006 \\
\hline Total hardness & IS 3025 P-21: 2009 \\
\hline Total dissolved solids & IS 3025 P-17: 2006 \\
\hline Total suspended solids & IS 3025 P-16: 2006 \\
\hline Chlorides & IS 3025 P-32: 1990 \\
\hline Sulphates & IS 3025 P-24: 2009 \\
\hline
\end{tabular}

\section{RESULTS AND DISCUSSIONS}

The results of the tests have been discussed as follows:

\section{A. $p H$}

$\mathrm{pH}$ is the parameter which determines the acidity or basicity of water [6]. It is measured using a digital ph meter. The sites analysed here, have shown no significant variation in the $\mathrm{pH}$ levels at the entry and exit point for each city. The BIS (Bureau of Indian standard) limits for drinking water $\mathrm{pH}$ range from 6.5 to 8.5.The results in Fig. 1 shows that this limit is not exceeded in any of the cities.

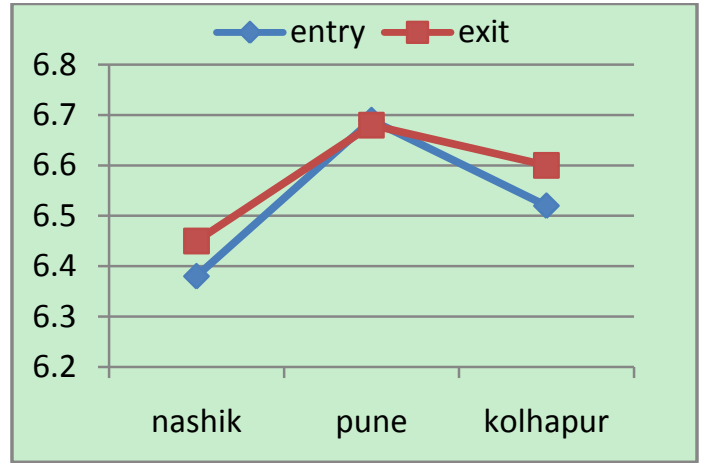

Fig. 1. Fluctuations $\mathrm{pH}$ values at the sampling points.

\section{B. DO (Dissolved Oxygen)}

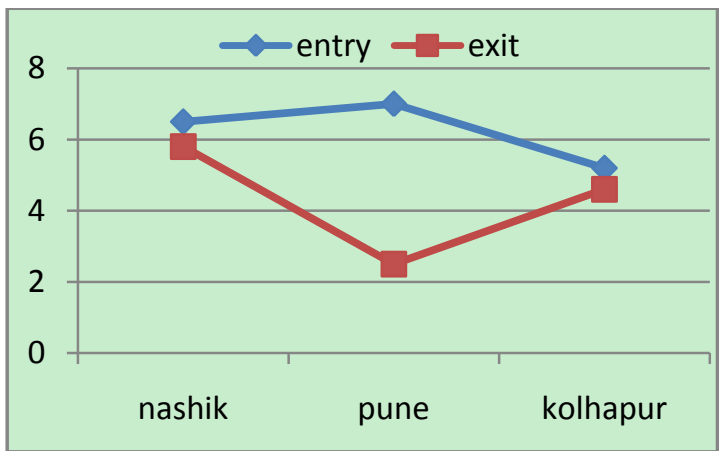

Fig. 2. Fluctuations in DO levels at the sampling points (Values in ppm).

The amount of atmospheric oxygen that dissolves in water and is available to the aquatic life for synthesis is termed as dissolved oxygen [6]. Here in the obtained results a change can be seen in the DO levels at the entry and exit points of each city. Accordingly the maximum difference from the plotted graph Fig. 2 can be obtained for the city of Pune with a DO difference of almost 4.5 followed by Nasik and Kolhapur. This DO content has reduced on account of increased eutrophication caused by sewage and industrial effluents discharged in the river during its flow through the city. When the aerobic microorganisms in the water increase, the amount of oxygen decreases disturbing the natural equilibrium of the river. Increased Urbanization and Industrialization caused stress on the self-purification mechanism of rivers [7] which depends on the DO content.

\section{BOD (Biochemical Oxygen Demand)}

The amount of oxygen needed for the oxidation of organic matter under aerobic conditions is termed as BOD. The maximum BOD difference between the entry and exit point is seen for Pune with Nasik and Kolhapur trailing each other as seen in Fig. 3. DO and BOD are inversely proportional hence decrease in DO level increases BOD. This states that Pune has largest amount of organic matter. This organic matter gets mixed in the river due to excessive discharge of domestic sewage and from industries such as sugar mills, pulp and paper industries etc. This in turn affects the self-purification capacity of river water [8].

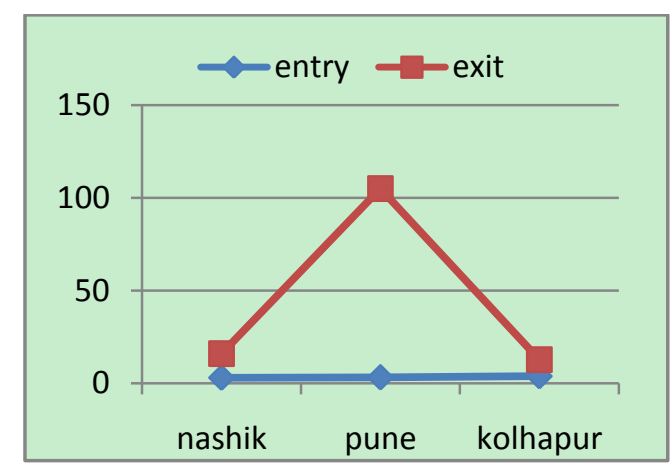

Fig. 3. Fluctuations in BOD levels at sampling points (Values in ppm).

\section{COD (Chemical Oxygen Demand)}

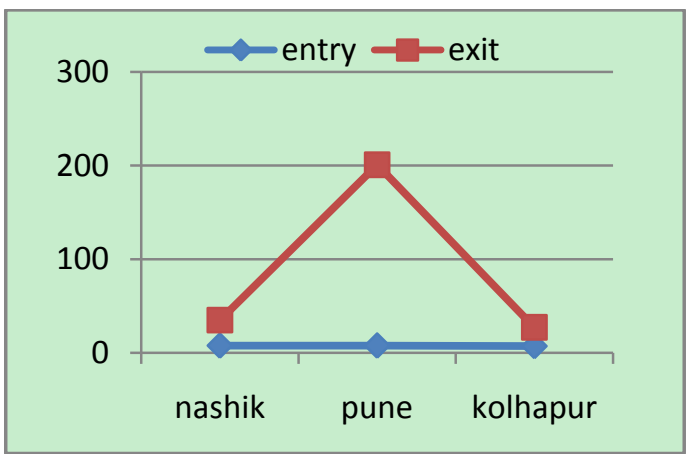

Fig. 4. Fluctuations in COD levels at sampling points (Values in ppm).

The amount of oxygen needed for the chemical oxidation of organic matter using oxidizing agent such as dichromate in acid solution is considered as COD. A similar trend which is seen BOD is also seen for COD from Fig. 4. Pune again is seen to have a very large difference in the values between entry and exit point. The difference for Nasik and Kolhapur is not so high. COD difference obtained is about $200 \mathrm{ppm}$ while BOD difference is about $110(\mathrm{ppm})$ which implies the presence of higher amount of chemically 
oxidizable matter, most of which is non-biodegradable [9]. This inorganic content is present majorly due to industrial effluents containing elements like nitrates, zinc, magnesium, cobalt, nickel etc.

\section{E. TSS (Total Suspended Solids)}

The floating impurities present in form of paper, plastic, dust particles, nirmalaya(flowers used for worship) debris and all other forms of solid waste which do not settle in water are termed as TSS. The total suspended solid in effluent water is more than inlet water due to organometallic compounds and organic sludge [10]. A significant TSS difference is observed in Pune from Fig. 5. Nasik and Kolhapur being religious cities have a large amount of nirmalaya being dumped in the rivers. Hence TSS difference is also high in these places.

\section{F. TDS (Total Dissolved Solids)}

The solids which dissolve in water and cannot be separated by any physical and pass through filter paper of pore size 0.2 micron are TDS [6]. TDS are present in the form of colloidal suspension. Increase in presence of TDS in water increases the turbidity. The permissible limit for TDS is 500ppm [11]. The results for none of the cities have exceeded this range making the water potable. Though the water is consumable, Pune shows the largest amount of total dissolved solids (Fig. 6) followed by Nasik and Kolhapur indicating maximum pollution.

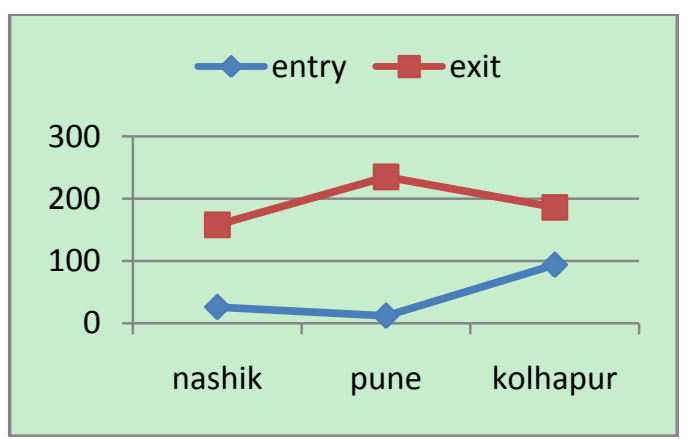

Fig. 5. Fluctuations in TSS values at sampling points (Values in ppm).

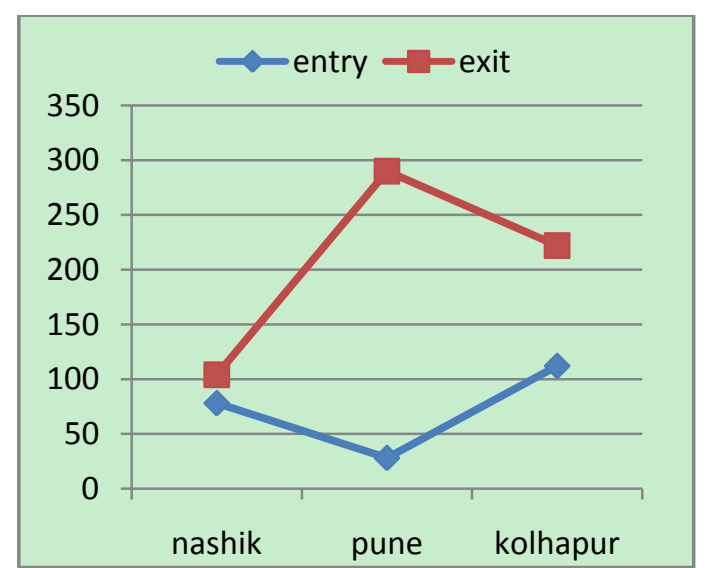

Fig. 6. Fluctuations in TDS levels at sampling points (Values in ppm).

\section{G. Total Hardness( $\mathrm{As} \mathrm{CaCO}_{3}$ )}

Hardness is presence of $\mathrm{Ca}$ and $\mathrm{Mg}$ ions in form of carbonates in water. When the river passes through any terrain, the salts present in soil below it get dissolved in water promoting natural hardness. Calcium and magnesium gets added due to industrial effluents majorly. Though the hardness is within the permissible range of 200ppm [11] the maximum difference is observed for Pune (Fig. 7) followed by Nasik and Kolhapur.

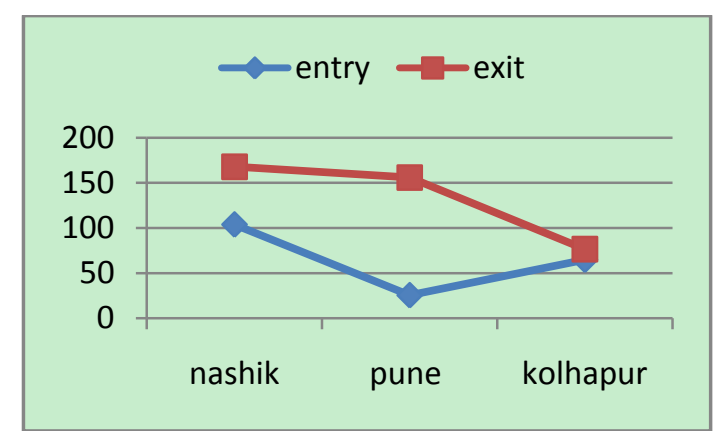

Fig. 7. Fluctuations in total hardness levels at sampling points (Values in ppm).

\section{H. Sulphates and Chlorides}

Chloride and sulphate content increases in water due domestic sewage which is high in $\mathrm{NaCl}$ content and sulphates also. Maximum difference in chloride and sulphate values is for Pune followed by Nasik and Kolhapur (Fig. 8 and Fig. 9) as it has the highest population.

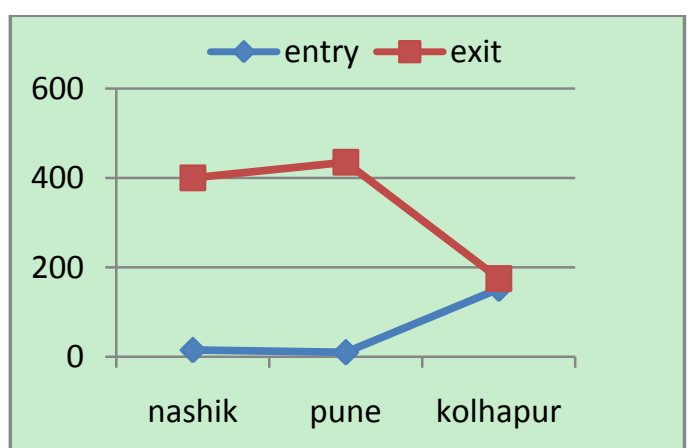

Fig. 8. Fluctuations in sulphate levels at sampling points (Values in ppm).

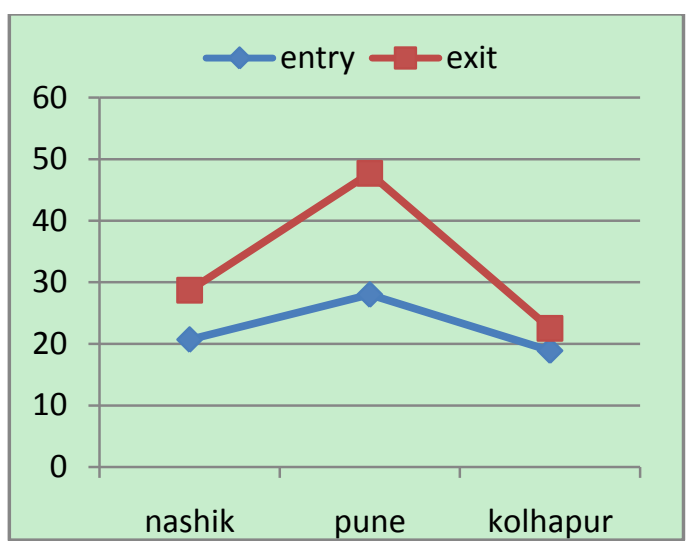

Fig. 9. Fluctuations in chloride levels at sampling points (Values in ppm).

\section{Total Coliform and Feacal Coliform}

The coliform count is the amount of coliform organisms present in water. The maximum difference in coliform count and feacal coliform is seen for the city of Pune (Fig. 10 and Fig. 11). This difference is nominal for Nasik and Kolhapur. This implies that the water in Pune suffers the highest amount of feacal contamination which comes in from domestic sewage. The coliform count is not affected by industrial effluents.

Hence, the results clearly state the difference in parameter 
levels at entry and exit points of each city.

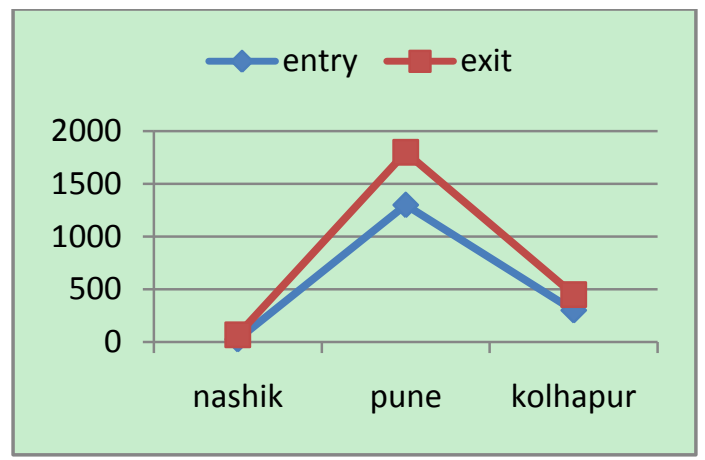

Fig. 10. Fluctuations in total coliform counts at sampling points (Values in MPN).

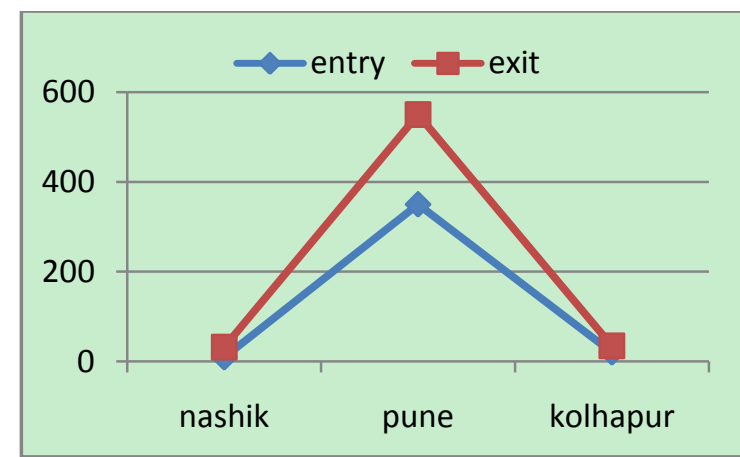

Fig. 11. Fluctuations in feacal coliform counts at sampling points (Values in MPN).

\section{CONCLUSION}

It can be concluded from the various parameters that the city which has an increasing trend of industrialization also has the maximum water pollution. This confirms that industrial effluents and domestic sewage have caused inimical effect on river water. Thus, the water in Pune is polluted to the greatest extent followed by Nasik and Kolhapur. This is also same trend for the development of these cities confirming that deteriorated water quality can be used as a measure for development of cities. This scenario calls upon the need for more research in this particular area to provide the upcoming generations with a better and cleaner environment.

\section{REMEDial MEASURES}

Certain measures can be implemented to abate this pollution. They are stated as follows:

1) The sewage must be collected and treated at community level rather than that at city level.

2) Ensure propermaintenance and functioning of treatment plants.

3) Effluent treatment plants must be setup for individual industries.

4) Stringent laws by the government about waste disposal in rivers and stricter implementation.
5) The public should be made aware about the importance of environmental degradation.

\section{REFERENCES}

[1] R. Bajpai, "Comparative analysis of physic-chemical parameters of Hasdeo River Barrage and Apra River water samples of BilaspurRegion," International Journal of Scientific and Research Publication, vol. 2, issue 9, September 2012.

[2] DAE Report, Maharashtra Government, India, 2008.

[3] A. Rahman and M. O. Chugtai, "Regional interpretation of river Indus water quality data using regression model," African Journal of Environmental Science and Technology, vol. 8, no. 1, pp. 86-99, January 2014.

[4] P. Dandekar, "River stories in Maharashtra - Many morals to learn," South Asia Network on Dams, Rivers and People, December 2011.

[5] Methods of sampling and test (Physical and Chemical) for water and waste water. [CHD 32: Environmental Protection and Waste Management], Bureau of Indian Standards, Government of India.

[6] Metcalf and Eddy, Wastewater Engineering, 4th edition, 2003.

[7] D. Florescn, C. Sandru, A. Iordache, M. Culea, and R. E. Ionete, "The influence of pollution monitoring parameters in characterizing the surface water quality from Romanian Southern area," September 2010.

[8] S. S. Patil and I. B. Ghorade, "Assessment of physico-chemical characteristics of Godavari River water at Trimbakeshwar and Kopargaon," Indian Journal of Applied Research, vol. 3, issue 3, March 2013.

[9] P. Raja, A. M. Amarnath, R. Elangovan, and M. Palanivel, "Evaluation of physical and chemical parameters of river Kaveri, Tiruchirapalli, Tamil Nadu," Journal of Environmental Biology, September 2008.

[10] F. Fadaeifard, M. Raissy, M. Faghnani, A. Majlesi, and G. N. Farahani, "Evaluation of physicochemical parameters of waste water from rainbow trout fish farms and their impact on water quality of Koohrang stream- Iran," International Journal of Fisheries and Aquaculture, vol. 4, no. 8, pp. 170-177, September 2012.

[11] Indian Standard: Drinking Water-Specification IS 10050, 2002.

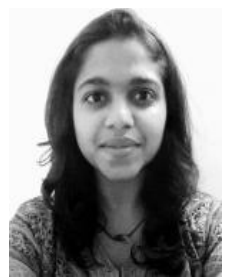

Priyanka K. Gadhave was born on 13 July, 1993 in the Ahmednagar, Maharashtra, India. Currently she is studying in the third year of the bachelors' degree in environmental engineering from Maharashtra Institute of Technology from Pune University, Maharashtra, India.

She holds the position as director at MauliSchool and Workshop for mentally retarded children, Ranjangaon, Ahmednagar, Mahrashtra, India. She has published two research papers on material sciences and Nanotechnology in the year 2013 in World Congress on Engineering by IAENG. She has addressed a national level political conclave named Indian Student parliament.

Ms. Priyanka is also a member of SAE: The Engineering Society for Advancing Mobility Land Sea Air and Space.

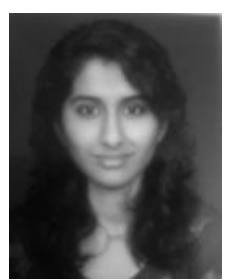

Akanksha Haribhau Kawade was born on 29 September 1992 in Nasik, Maharashtra, India Currently she is studying in the third year of bachelor's degree in environmental engineering from Kolhapur Institute of Technology from Kolhapur university, Maharashtra, India.

She has participated in training programs like GIS(global positioning systems), National level student political conclave named Indian Student parliament and conference like Indian Science Congress.

Ms. Akanksha H. Kawade is also a student member of the Indian Society of Technical Education, New Delhi, India. 